WellBeing International

WBI Studies Repository

1986

\title{
Horsebreakers, Tamers, and Trainers: An Historical, Psychological, and Social Review
}

Sharon E. Cregier

University of Prince Edward Island

Follow this and additional works at: https://www.wellbeingintlstudiesrepository.org/acwp_ewp

Part of the Agribusiness Commons, Animal Studies Commons, and the Business Law, Public Responsibility, and Ethics Commons

\section{Recommended Citation}

Cregier, S.E. (1986). Horsebreakers, tamers, and trainers: An historical, psychological, and social review. In M.W. Fox \& L.D. Mickley (Eds.), Advances in animal welfare science 1986/87 (pp. 89-101). Washington, DC: The Humane Society of the United States.

This material is brought to you for free and open access by WellBeing International. It has been accepted for inclusion by an authorized administrator of the WBI Studies Repository. For more information, please contact wbisr-info@wellbeingintl.org.

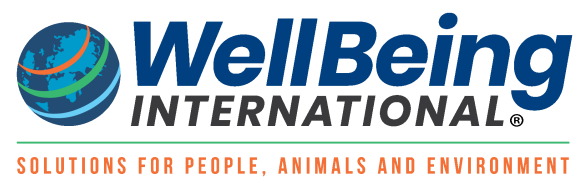




\title{
HORSEBREAKERS, TAMERS, AND TRAINERS: AN HISTORICAL, PSYCHOLOGICAL, AND SOCIAL REVIEW ${ }^{1}$
}

\author{
Sharon E. Cregier ${ }^{2}$
}

If racing with mere men has wearied you,
how can you contend with horses?

Jeremiah $12: 5$

To my knowledge, there has been no organized synthesis describing the historical development of horse handling, management, lore, and training. This discussion offers, in capsule form, some of the historical, psychological, and social considerations which might be taken into account when evaluating horse-handling skills.

First, I would like to describe the natures of the emotional and psychological bonds between man and horse. I will also look at the consequences of various types of bonding on horsemanship or management. We can increase our understanding of the role of the horse in our history and lives by thus seeing how the animal figures in our fantasy, and in our practice (Rhodes 1980; Van de Castle 1983).

For $98 \%$ of the last 6000 years - up to 1839 - the horse was the fastest vehicle available to man. As such, it was easily associated with virtually anything, however unrelated, that offered power and speed. In our dreams and in our lives, from time immemorial, the horse became the archetype, the ready reference, for this association (Barclay 1980).

Certainly, for most of us, no other creature combines "grace, streamlining, intelligence, and tractability" so well with power and speed. The horse is at once powerful, practical, and beautiful (Barclay 1980; Jung 1956).

Artists have been very quick to extol these aspects of the horse (Rhodes 1980). A woodcarver of children's rocking horses, Tilo Kaufmann, utilizes horses with impossibly powerful stout legs to emphasize the sure victory of his horses over the demons writhing between their hooves (Rettig 1980). Where the supernatural demons fail, practical man wins, as depicted in a similarly powerful carving outside the Federal Trade Building in Washington, DC.

Today, popular psychology treats the horse as a muscular, masculine symbol. That this identification is rather simplistic, perhaps even banal, has been challenged by more thoughtful observers. Like the artists depicting equine themes, their horses support a variety of symbolic meanings. 
For the juvenile, the horse may represent escape from a confusing world to disciplined freedom. For others, the horse is symbolic of work, service, help, and action.

For literary men such as George MacDonald, the horse symbolizes control of will and imagination, and partial reconciliation of the female abuse of sex (which is power) and the male abuse of sex (which is sensuality).

The Jungian psychologist sees the horse as symbolic of feminine attributessuch as alleged unpredictability, capriciousness, and beauty - and a strong mother symbol (Jung 1956).

As representative of a variety of human desires, needs, and perceptions, the horse is far less consistent than the dog, wolf, or ape. These animals are frequently viewed as having such largely masculine attributes as leadership, strength, and predatory skills (Jones 1983).

The lack of consistency in horse symbolism argues against one of popular psychology's pet hypotheses: that the attraction of the horse, for females especially, is chiefly the opportunity it offers to work out sexual conflicts. But this can be argued for other activities as well, and far more convincingly.

For example, the sexual conflict theme is resoundingly portrayed in bull riding in rodeo. In fact, the conflict is not worked out or resolved in this event so much as it is reinforced. The stereotypical perversions of masculine dominance through muscular strength - brawn, not brain - remain (Lawrence 1982).

Because of its varied associations, the horse offers a broad opportunity for youngsters to work out and establish current and future roles as partner, parent, boyfriend, girlfriend, or child. Interviews with juvenile horsemen by researcher Barbara Jones of the University of Pennsylvania established many such linkages.

For the most part, the young female riders showed themselves to be very adept at empathy with their horse, subtle direction,and physical balance. It was the males who had to be taught that the horse, to be mastered, must be outwitted, not overpowered. Some males, to their cost, learn this lesson almost too late in life, or not at all, as we shall see later when we discuss types of horse management and veterinary care.

When the thoroughly active horseman is studied, there is some argument to support popular psychology's contention for the physically sexual attraction of the horse for both male and female. Daily, fresh-air interaction by a psychologically sound person with an animal as demanding as the horse cannot help but contribute to an overall feeling of well-being. This feeling carries over into other activities, including but not limited to sexual (Jones 1983).

But the same can be said for other strenuous pastimes, whether jogging or kite-flying. Working with horses involves mucking out stalls, cleaning gear, fixing fence, humoring farriers, seeing to trailer repairs; adhering to a relatively inflexible schedule of feeding, veterinary attention, and grooming; paying out really staggering sums of money throughout the year; exposing oneself to the danger of kicks and falls; and having to continually concentrate on the animal in hand. Certainly there are more pleasant ways of obtaining peak 
peak physical efficiency and maintaining a rich supply of the euphoriaproducing beta endorphins associated with regular exertions.

All these different equine activities attract different types of people. Depending on the needs of the person drawn to the horse, this animal-especially because of its ambiguous symbolism, from masculine to feminine, from strength to frailty - is able to facilitate the expression of various components of the human personality.

Not all of these expressions are, of course, desirable. Authors have used the less attractive outcomes of human-horse associations with telling effect. For example, in Verner von Heidenstam's The Cbarles Men (1920), or in J.V. Jensen's The Fall of the King (1933), the alienated heroes require horses and either treat them cruelly, or in a showily generous fashion. H.C. Branner's The Riding Master (1951), is a commentary on this Nazi type.

In a more positive description of the symbolic and actual association between horse and man, C.S. Lewis in The Great Divorce (1978) uses the horse as a symbol of the divine steed, or reconciled will and imagination, which carries the soul so blessed to God (Meilaender 1978). Rooted in the collective unconscious of mankind, the theme is universal. At the Cultural Festival of India in London (July 16-August 15, 1985), The Swaminarayan Hindu Mission used horses over the welcoming gate to symbolize the soul's journey to God. The seven spirited horses, reined by God in a chariot carrying the soul, represented the five senses plus mind and subconscious.

As in literature and spiritual quest, so in life. Both the desirable and undesirable facets of our association with horses are represented in three basic approaches to our management of the horse. I have divided these approaches into three broad categories, the mechanistic approach, the shamanistic approach, and the pragmatic approach. While there is some overlapping between the three, each retains distinctive characteristics.

The mechanistic approach usually insists that the horse is worthy only when it is useful or paying for itself. And payment should be in cash. The mechanistic approach is distinguished by the practice of physical dominance over the animal, usually by the crudest tools - such as whip, chain, strait jacket, reliance on chemical controls, quick-fixes, and physical exhaustion of the animal to bring it under control (figure 1).

There is no attempt to see the horse as an individual. The mechanist sees the horse as a device for enhancing his own ego and offers nothing to the animal in return. He may argue against developing an affection for the horse, lack of affection denoting maturity and a "civilized" approach (Midgley 1984a). The mechanist nurtures callousness by limiting emotional commitments. Because it requires identification with the animal, understanding is feared and suppressed (Midgley 1984b). The horse is thus viewed as essentially a tool, a barely sensate creature.

The mechanist is also distinguished by a tendency to put his own interests first and to overwork the animal. It is noteworthy that at the time in history when cruelties to the horse were most rampant, this view prevailed. It was 
partly to combat this evil that Black Beauty was written in 1877 (Blount 1974). This book-which led to the abolition of the bearing rein - continues to have enormous influence on the treatment of horses.

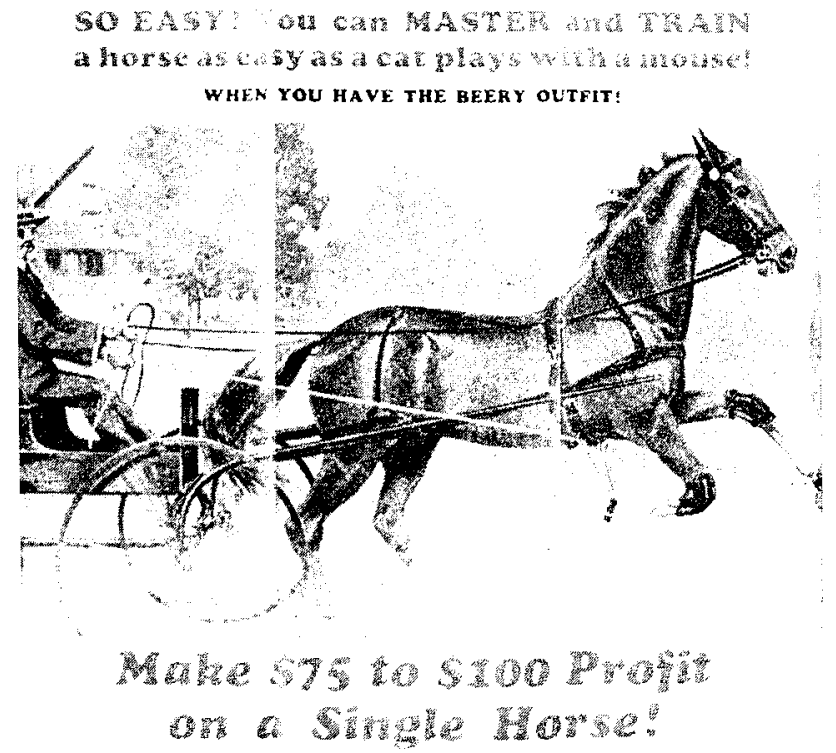

Figure 1. The horse's first line of defense--head-long flight from fearful stimuli - is checked by the mechanist's running-w rig. This system is still used by horse-dependent cultures in North America. (Advertisement reprinted with permission by the Beery Correspondence School of Horsemanship.)

That the battle against the extremes of mechanism is far from over, is witnessed by the efforts to halt its cruelties in the performance horse industry. It has recently been announced, for example, that all Arabian horses entered in certain competitions must be examined for whip marks, drugs, abusive equipment, correct hoof lengths and evidences of the use of ginger in the rectum. Exhibitors found to have whipped, frightened, or abused their animals will not be allowed to enter the event (IAHA 1985).

The shamanistic approach to controlling the horse is far more subtle. Sometimes, it is too subtle for both the practitioner's, and the horse's, own good. Those thought to be too close to their horses have been burned - with their horses - as witches (Howey 1958).

The shaman's, or magician's, approach is based on the closest possible empathy with the horse, an empathy which comes from long observation, practice, modification, concentration, and questioning. This is probably the hardest route of all to the most successful horse management. It is in constant flux, very little understood or appreciated even today. 
Possibly this lack of appreciation is because, when exhibited, shamanism offers little in the way of entertainment (such as does the mechanistic approach) and much in the way of education. It is never as sensational as, say, mid-nineteenth century horsetamer Prof. Silas Sample's horse-taming machine. This was a rotating platform on which the unbroken or savage horse was driven and then rotated until it fell down in a dizzy stupor (Hayes 1895).

Today, while we no longer burn our horse shamans at the stake,we do send them to Coventry. When a twentieth century exponent of kindness to the horse, Ray Hunt, promulgates his theory and practice, it is not unusual for a bow-legged, saddle-weary member of the audience to shake his head and mutter, "Kindness to the horse. It just won't work, no matter what this buckaroo says or does" (Heminway 1981).

Ray Hunt has lots of company in Coventry. Among them is probably one of the greatest horsemen of the nineteenth or any century, John Solomon Rarey (figure 2). Rarey's specialty was the savage stallion and other abused horses (figure 3).

While Rarey had a simple approach to first immobilizing and then gentling these animals, it was an approach he insisted be coupled with kindness. He was also careful to emphasize to his incredulous audiences that the horse was capable of feeling and affection.

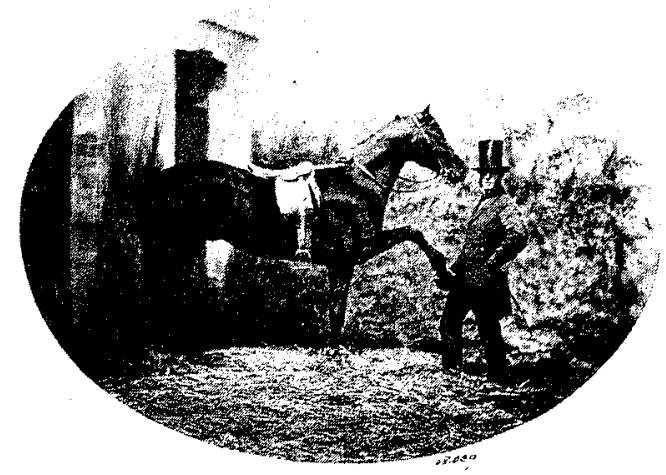

Figure 2. Lord Dorchester's "savage stallion," Cruiser, signals his confidence in the American trainer, J.S. Rarey, with softened eye, alert ears, and relaxed foreleg. Rarey saw himself as an "educator, not a gladiator." (Photo courtesy of the trustees of the Victoria and Albert Museum.)

In the wrong hands, Rarey's initial handling of a savage or simply recalcitrant animal could only worsen the situation. For this reason, he took a typically shamanistic precaution: limiting his audience to the so-called better, or more refined, social classes-among them dukes, duchesses, barons, baronesses, princes and princesses-for a substantial fee (figure 4). 


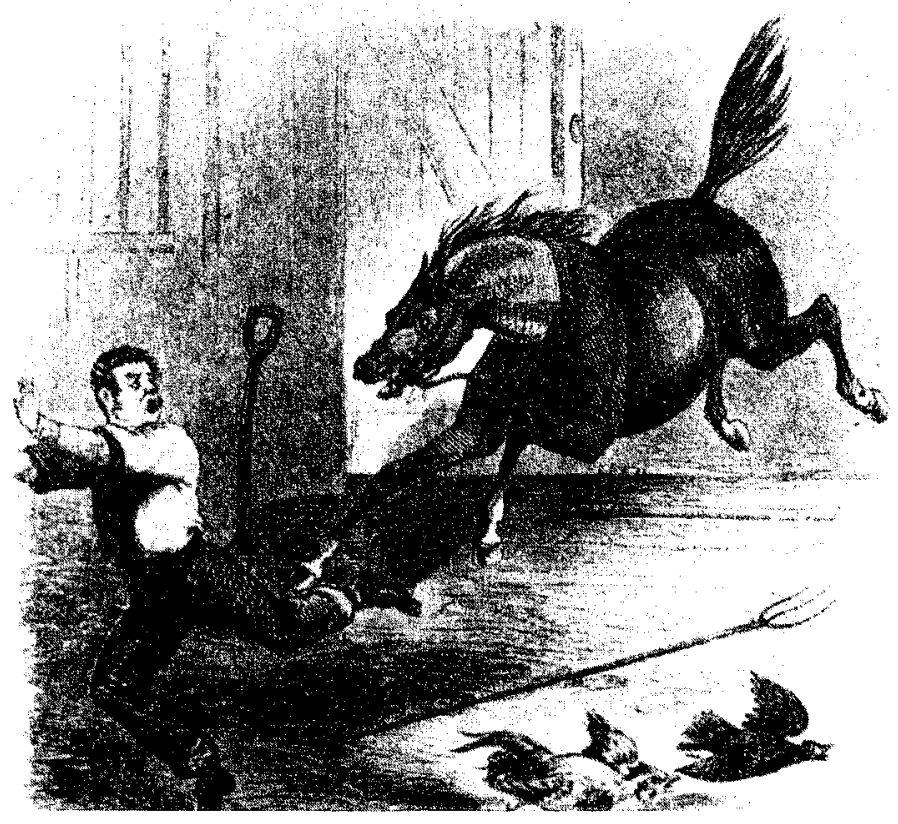

Figure 3. An Equestrian Humane Society, proposed Punch in May 1858, would sponsor Rarey as a "groom tamer." But, as Rarey's system worked through the affections, how could he influence brutes with no affection? The tamer's approach would end the horsebreaker's dependence on starvation, drenches, twitches, roweled bits, spurs, and-at times-blinding. (Slide credit: Dan MacKinnon. Reference: Puncb [1985]. Illustration: Harper's Montbly Magazine. Vol. 22, 18611862, p. 615.)

In this Rarey was consciously or unconsciously following another attribute of shamanism: initiation of the chosen few. For centuries the blood horse, especially, was the prerogative of the rich and powerful. Its ownership, care, and training were under the direction of its wealthy owner. The first horse training books were written not for the unlettered man in the stable, but for persons of position.

We can see this association of training with the "better classes" even in such a democratic society as North America. Posters depicting horsetaming sessions frequently picture the tamer dressed in formal wear, top hat and all. He might have the cavalry stripe down a trouser leg, again another symbol of exclusiveness. He was often referred to as "Professor." The reference was not to a degree holder, in this instance, but to someone who did not have to earn a living by getting his hands dirty.

Bad trainers were invariably pictured as loutish, leering, squat ignorants whose closest association with a stable should, by rights, simply be to remove the dung (figure 5). They had their historical roots in the footmen once 


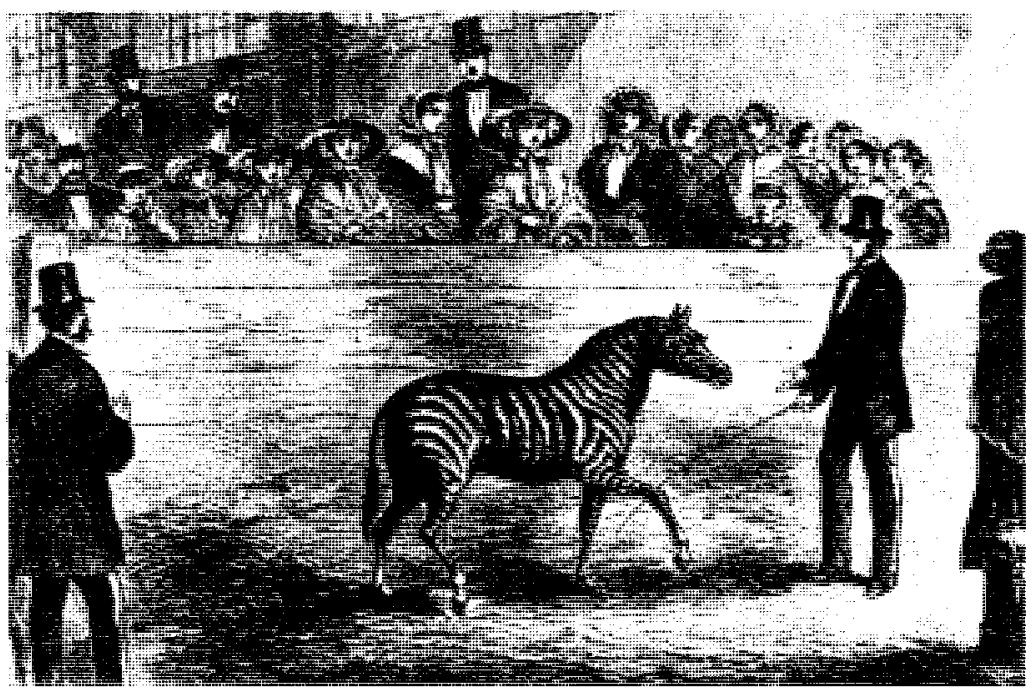

Figure 4. Cavalry-striped trousers befit a royal audience. Before taming by Rarey, the Zoological Society of London's zebra would suspend itself by its teeth from its hayrack, flailing its four hooves in all directions. Or it would walk on its hind legs, tearing at the rafters (Thorpe 1861). Zoo veterinarian Oliver Graham-Jones notes (1970) that "A zebra wills its body to kill you... [it] is the only animal I know of that can leap with all four feet off the ground and bite and kick you before it touches the floor again." (Slide credit: Dan MacKinnon. References: Graham-Jones, O.[1970]; Thorpe, TB.[1861]. Illustration: The Review. Vol. II, No. 29, July 17, 1858, p. 41.)

selected for their "terrible voices, cruel looks," for the specific purpose of cudgeling, beating, pushing, burning, and berating a horse into compliance with its master's wishes (Chenevix Trench 1970).

Where shamanism is concerned, exclusivity persists today in a society formed, it is said, before the time of Solomon. This is the secret Society of Horsemen. Still extant in England's East Anglia and in Scotland (Evans 1979), its initiation rituals have much in common-according to one anthropologist - with animal cults around the world, notably West Africa (MacLean n.d.).

Members were chosen for initiation into the Society on the basis of their facility to work with horses. However, these were men from the hired horsemen class and not the land-owning or upper classes. By learning the secrets of control-such as mental summoning of one's horse over a great distance - and veterinary care over the horses placed in their charge, the horsemen were able to protect their livelihood, and the horses assigned to them for breaking or working.

Like many other types of shamans, they enjoy a sense of power and sacredness, shared by ritual and pledge, and historically rooted in such 
traditions as Daniel in the Lion's Den, Elijah fed by the ravens, and, chief of all, St. Francis of Assisi (Savishinsky 1983).
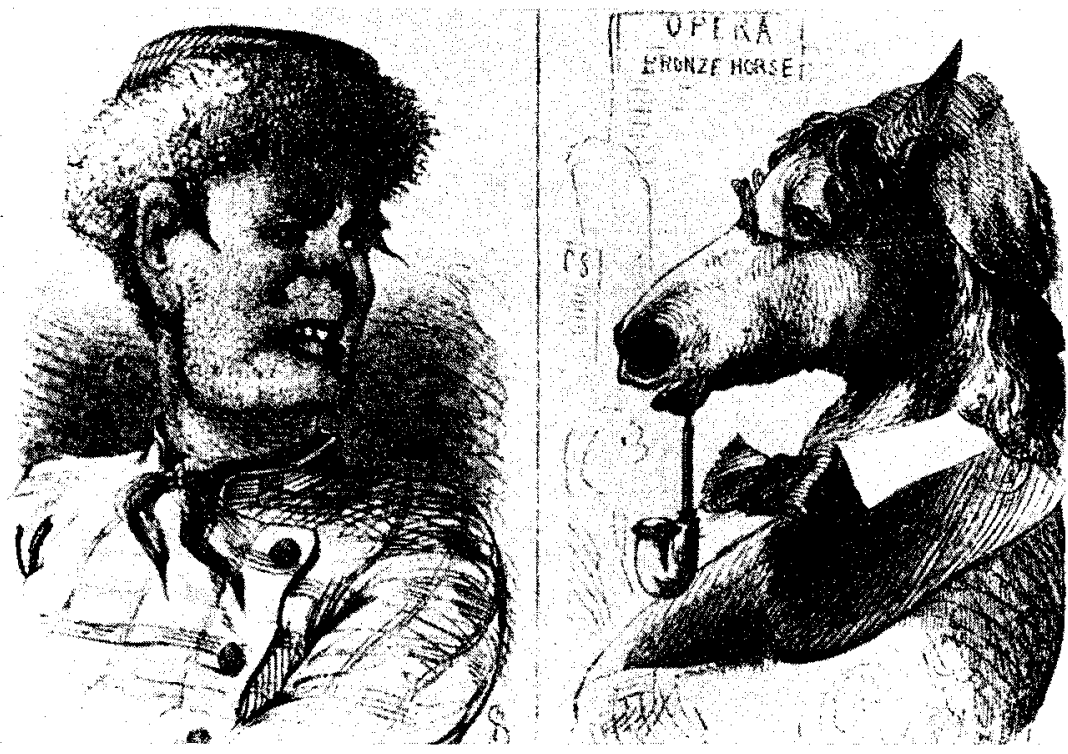

Figure 5. Charles Dickens's journal for July 1858, Housebold Words, pleaded with Rarey to form classes for grooms. "Unless the crust of mannerism and self-conceit of these men is broken down, the horse is still in the Iron Age!" (Dixon 1858). Rarey's methods, based on the horse's "intellect and affections," gave impetus to better treatment for the insane, were adopted for the classroom, and influenced the emerging humane movement. (Slide credit: Dan MacKinnon. References: Dixon, HH. [1858]. Illustration: Harper's Monthly Magazine. Vol. 22, 1861-1862, p. 620.)

Strict discipline within the order and commitment to their horses, ensures that the secrets they learn are not used to the detriment or harm of the horse.

Other than secret signs identifying members to each other, they also share a password which is still unknown to this day. It has been guessed at, however, and is significant for its implications: Both in One.

The secret Society's initiation ritual, for example, usually includes a hairraising experience for the initiate which parallels the fear that a horse experiences in a novel situation. At the peak of the initiate's fright, a brother horseman appears to calm the initiate and take charge.

This intense preparation for working with horses, the practiced concentration, leads to a feeling of unity with the horse: Both in One. Horse and man together are greater than either alone (Evans 1979). A loss of the sense of self is experienced, similar to the loss of self (unmourned) when one is composing music or participating in a ritual. In such a state, the question, 
Am I doing well? does not occur (Csikszentmilhalyi 1975). Once again, he that loseth his life shall save it. Thus moral (i.e., non-coercive) control of and empathy with the horse is developed.

There is little that is openly flamboyant about moral control of a horse as opposed to physical, mechanical control. The shamanistic approach requires a person who is confident and sure of himself without arrogance or ignorance.

The third approach to the horse is that of the pragmatic. Unfortunately, on close examination, it often turns out to be self-defeating. The practitioners of this approach shun the refining of critical judgment even as the shaman seeks it.

Thus a slavish conformity to the past is one of the most prominent features of this approach. It is easier to memorize the shibboleths that pass for knowledge. Probably no other area of human endeavor is so steeped in conservatism as that of our association with the horse. The Grandfather Syndrome is entrenched. "What was good enough for Grandfather is excellent beyond all improvement." We see it in every aspect of our handling of horses: whether in perpetually darkened or needlessly artificially-lit stabling, in the persistence of the barbaric practice of firing in veterinary care (Eley 1982; McCullaugh and Silver 1981); or, in the training ring, the insistence that the horse's virtually rigid thoracic spine is bending in a continuous arc when circling under tack and rider (Crossley 1983).

Each one of these practices is excused on the basis of being "practical." It took decades before the forward seat was finally accepted for jumping, cross-country, and racing. Italian cavalty officer Federico Caprilli's (1868-1907) forward seat was a carefully thought-out, logical proposition and practice. However, it was opposed by the "pragmatists." They believed, for example, that on descending from a jump the rider must lean backwards to save the horse from the jar of the rider's weight on landing, and to save it from a fall if it stumbled.

Caprilli, however, simply brought the rider's center of gravity forward, absorbing the shock of the landing in the rider's flexed leg and thigh joints. He correctly pointed out that however one sat the horse, the weight of the horse and man must inevitably be borne by the horse's forelegs and the forward position made it less of a jar for the horse. Certainly a rider could not save his horse from falling by a tug on the reins. If he could, flying would be a simple proposition (Chenevix Trench 1970). By asking the rider to conform to the horse's center of gravity, and not the horse to the rider's, Caprilli stirred up a storm which is not yet dead.

The development of scientific tools of proof did little to dispel firmly entrenched "beliefs as facts" about the horse. When Eadweard Muybridge published his detailed photographic work, Animals in Motion (1887), proving that the horse at a full gallop suspends and bunches all four feet under its belly, horsemen refused to accept the evidence (Ozment 1985). 
Centuries earlier, the first evidence of horses in use shows them harnessed as cattle had been, to a central draft pole beneath a yoke. It wasn't until 3000 years later that the shaft and breastcollar harness, giving an economical, efficient single draft, came into use in the 3rd century BC in Han China (Littauer and Crouwel 1979).

This, and more, forces us to the distasteful conclusion that if horsemen are not exactly a bright lot, they are certainly conservative.

Today, we are still plagued with the allegedly "practical" interpretation of equine character according to head bumps, hair whorls, and number of white legs. Much of this is contradictory and, I'm certain, self-fulfilling prophecy. The chief function of such classifications seems to be to allow the handler to blame the horse for not adapting to the trainer,and perhaps even to set up the circumstances that allow the horse to react that way.

The mechanist and the pragmatist are united in their separation from the earlier shamanistic wisdom. To paraphrase and update C.S. Lewis (1947):

For the shaman the cardinal problem is how to conform the soul to reality, and the solution had been knowledge, self-discipline, and virtue. For the mechanist and pragmatist alike the problem is how to subdue reality to the wishes of men: the solution is a technique: and both, in the practice of this technique, are ready to do things hitherto regarded as disgusting and impioussuch as the mutilation of horses' feet and hooves by the Tennessee Walking Horse "industry," or the refusal to guard life by wearing protective head gear in Western riding events (Marcovitz 1985).

What are the distinguishing characteristics of the genuine horseman, as opposed to someone with a horse? It would seems that the genuine horseman first of all realizes that one cannot compartmentalize one's study of the horse.

It is one thing to study the hormonal dysfunction in horses being transported. It is another to realize that before these dysfunctions can be mitigated or eliminated, one must go beyond physical or chemical control or restraint of the transport situation. One must look into automotive and equine dynamics: the simple physics of forward and reverse, and side to side motion, and how the balanced, stationary stance is maintained by sympathetic motion or exacerbated by contra-indicative motion.

It is essential in virtually any endeavor with the horse, and not just in the area of transport, to have a knowledge of equine behavior. For example, the fact that horses are sensitive about activity in their blind zones ("hind is blind") affects every aspect of their handling, from stabling to training and transport. The biomechanics of equine anatomy must be studied. Even the bond of trust established, or not established, between the horse and its handler must be investigated.

By willingly extending his range of interests, the genuine horseman becomes perhaps one of the most authentic of world citizens, able to appreciate and sympathize with an everbroadening range of problems and interests. He becomes a person welcome at every level of healthy society, being 
accustomed to developing an eye for the meaning of cross-cultural signals, both alien (read inter-species) and familiar (read intra-species) (Stein 1964).

These increased contacts invariably remind the horseman of his own deficiencies in handling skills and understanding. But the skilled, mature horseman will respond to these realizations in a positive manner, selecting those new practices which will benefit the horse. He thus increases his value to horses and humans by upgrading his own skills.

This is especially important, but not always realized, in the veterinary field. Practitioner Robert Miller of California has documented the tendency of North American veterinary schools to reinforce the mechanistic approach to animal handling.

"No other horsemen," says Miller, "must handle as many horses as does the equine practitioner in a normal working day and under such disadvantageous conditions." To compound the difficulty there was nothing in the veterinarian's training in the schools he visited in North America or Europe to utilize equine psychological principles to control the horse.

While any veterinarian can learn the psychological methods of control, said Miller, not every male veterinarian is receptive. Those veterinarians who are, are almost always over forty years of age. Miller found that female veterinarians are much less likely to elicit the fear-flight response in horses, but rarely is a man under forty years of age willing to try other than the mechanistic methods of restraint.

"Somewhere around forty years of age," says Miller, "we start to enjoy outwitting our patients rather than outfighting them.... It is safer, more humane, better technique professionally, less hazardous, more enjoyable and more effective" (Miller 1984).

Miller's preferred technique of psychological control epitomizes the chief aspect of the good horseman: He is very much aware of the life-threatening danger of a frightened horse. He is conscious of the need to maintain poise, balance, and a relaxed attitude when working with horses. And he avoids force and sudden movement (Roberts 1979).

Unconsciously, good horsemen have been imitating horse language to communicate with their animals. They may, for example, practice the herdmate's reassuring nibbling of the withers by scratching the same area in a tense situation. Trainers like Pat Parelli in Clements, California, consciously utilize eye contact and their own body language to train horses with minimal physical contact and minimal, or no, tack.

There is still further room for definitive studies on the relationship of the trainer to the animal as expressed by the trainer's facial aspect, posture, and vocalizations, together with the animal's response. How do animals respond toward trainers whose approaches to the horse and use of eye contact differ? To minimize biased reportings of such studies, it is suggested that a trained ethologist observe the interactions (Manning 1983).

Throughout history the record is clear. An accurate knowledge of horse behavior can make, or break, a campaign, whether on the field of battle 
(Cregier 1982), or in diplomacy. Horsemen of all stripes can, for example, appreciate the challenge offered to King Richard during the Third Crusade by his opponent, Saladin. Saladin sent Richard a fine charger. But Richard, who knew a thing or two, mounted an expendable groom on the animal which immmediately bolted back to the Saracen camp. Saladin then sent another horse without the homing instinct (Chenevix Trench 1970).

The contrast between good and bad horsemanship can be best summed up by this homily:

Good horsemanship is a thing of skill.

Bad horsemanship is a thing of courage.

Good horsemanship will last through age, sickness and decrepitude.

Bad horsemanship will last only as long as

youth and strength supply courage.

\section{Acknowledgement}

I am indebted to Professor Hamish Henderson of the School of Scottish Studies at the University of Edinburgh for so generously opening his archives on the Secret Society of Horsemen to this researcher.

\section{Endnotes}

${ }^{1}$ This paper was presented as part of an illustrated equine behavior seminar at Nova Scotia Agricultural College, May 11, 1985.

${ }^{2}$ The author is the North American editor of Equine Behavior Journal, University of Prince Edward Island, Charlottetown, PEI, Canada C1A 4P3.

\section{References}

Barclay, HB. 1980. The Role of the Horse in Man's Culture. London: JA Allen. 398 pp. p. 371.

Blount, M. 1974. Animal Land: The Creatures of Cbildren's Fiction. New York: William Morrow. 336 pp. pp.249-50.

Branner, HC. 1951. The Riding Master: London:Becker and Worburg. 159 pp.

Chenevix Trench, C. 1970. A History of Horsemanship. New York: Doubleday. 320 pp. pp. 89-90, 116-20, 248-69.

Cregier, SE. 1982. The Mare of Solomon's Song. Horseman. 26(8): March, 68,71.

Crossley, A 1983. Flexibility of the horse's spine: The full story. Equi. 16: 12-15.

.Csikszenmilhalyi, M. 1975. Play and intrinsic rewards. J. of Humanistic Psychol. 15(3): 41-63.

Dixon, HH. 1858. Horsetaming. Housebold Words. July 10. pp. 82-84.

Eley, JL. 1982. What the fire will not cure, nothing will cure? Equi. 11: 8-9.

Evans, GE. 1979. Horse Power and Magic. London: Faber and Faber. 222 pp. pp. 97-198.

Graham-Jones, O. 1970. First Catch Your Tiger. New York: Taplinger. p. 96.

Hayes, MH. 1896. Illustrated Horse Breaking. London: Hurst and Blackett. 381 pp. p. 176. von Heidenstam, CG. 1920. The Charles Men. New York: American Scandinavian Foundation. 556 pp. Heminway, J. 1981. The cowboy who respects horses. Quest. 5(5): 22-26, 84-86, 88.

Howey, MO. 1958. The Horse in Magic and Myth. New York: Castle Books. 238 pp. pp. 217-18. I[nternational] A[rabian] H[orse] A[ssociation] takes steps against abuse. 1985. Equus. August(94): 104. Jensen, JV. 1933. The Fall of the King. New York: Holt. 300 pp. 
Jones, B. 1983. Just crazy about horses: The fact behind the fiction. In: Katcher, AH and Beck, AM. New Perspectives on Our Lives with Companion Animals. Philadelphia: Univ. of Pennsylvania Press. pp. 87-111.

Jung, CG. 1956. Symbols of Transformation. Bollingen Series No. 20, Vol. 5. New Jersey: Princeton Univ. Press. 557 pp. pp. 207, 251, 274-75, 421-22.

Lawrence, EA. 1982. Rodeo: An Antbropologist Looks at the Wild and the Tame. Knoxville, TN: Univ. of Tennessee Press. 288 pp. pp. 180-98.

Lewis, CS. 1947. kThe Abolition of Man. New York: Macmillan. 121 pp. pp. 87-88.

-. 1978. The Great Divorce. New York: Macmillan. 128 pp.

Littauer, MA and Crouwel, JH. 1979. Wheeled Vehicles and Ridden Animals in the Ancient Near East. K. In: EJ Brill. 185 pp. pp. 9-12.

MacLean, U. n.d. Letter to Professor Hamish Henderson, School of Scottish Studies, University of Edinburgh.

Manning, A. 1983. Ethological approaches to the humancompanion animal bond. In Katcher and Beck, op. cit. pp. 7-16.

McCullaugh, KG and Silver, IA. 1981. The actual cautery: Myth and reality in the art of firing. Equine Vet. $J .13(2)$ : 81-84.

Marcovitz, S. 1985. A hard fight for hard hats. Equus. October (96): 73, 84-85.

Midgley, M. 1984a. Animals and Why They Matter. Athens: Univ. of Georgia Press. 158 pp. p. 122.

—. 1984b. Wickedness. London: Routledge \& Kegan Paul. 224 pp. p.4.

Miller, R. 1984. Equine psychology and its application to veterinary practice. Paper delivered to the Mid-Coast Veterinary Society, October 4, 1984, San Luis Obispo, California.

Muybridge, E. [a.k.a. Edward James Muggeridge]. 1887. Animal Locomotion. Philadelphia: Univ. of Pennsylvania. Unpaginated. 781 plates.

Ozment, J. 1985. Early equine photography. Nat. Sport. Lib. News Lttr. June (20): 2.

Punch. 1858. A hint to horse tamers. Vol. 34, May 8, p. 190.

Rettig, R. 1980. The eternal horse: Evoking a joyful event. Horse, of course! 9(12): 43-44.

Rhodes, B. 1980. The eternal horse: Capturing the horse's strength and emotion. Horse, of course! $9(12): 44-45$.

Roberts, T. 1979. Horse Control: The Young Horse. Richmond, Australia: TA and PR Roberts. 212 pp. p.205.

Savishinsky, JS. 1983. Pet ideas: The domestication of animals, human behavior, and human emotions. In: Katcher and Beck, op. cit. pp. 112-131.

Stein, E. 1964. On the Problem of Empathy. The Hague: Martinus Nijhoff. 113 pp. p. 105.

Thorpe, TB. 1861. Rarey the horse tamer. Harper's Montbly Magazine. XXII. No. 131. April 29, 1861. pp. 615-24,

Van de Castle, RL. 1983. Animal figures in fantasy and dreams. In: Katcher and Beck, op. cit. pp. $148-173$. 